\title{
Characteristics and prevalence of pterygium in small communities along the Solimões and Japurá rivers of the Brazilian Amazon Rainforest
}

\author{
Características e prevalência do pterígio em \\ comunidades ribeirinhas dos Rios Solimões \\ e Japurá localizados na Amazônia Brasileira
}

Lívia Adnet Martins Ribeiro', Luiz Felipe Guaraná Martins Ribeiro², Paulo Roberto de Azevedo Castro3, Fílicio Doné Lima da Silva ${ }^{4}$, Verônika Maria Weyll Adnet Martins Ribeiro ${ }^{5}$, Arlindo José Freire Portes ${ }^{6}$, Abelardo de Souza Couto Junior ${ }^{7}$

\begin{abstract}
Purpose:To evaluate the prevalence and characteristics of pterygium in small communities along the Solimões and Japurá rivers, State of Amazonas, Brazil. Design: cross-sectional study. Methods: This study was carried out on populations of the Brazilian Amazon rainforest. Data were collected by two separate ophthalmologists in three expeditions, covering 55 local communities. A total number of 1295 patients were examined, of which 659 were over 18 years old. The patients diagnosed with pterygium answered a questionnaire addressing gender, age and outdoor activity. Pterygium lesion sizes were graded as grade 1 (lesion covers until limbus), grade 2 (lesion covers cornea by $2 \mathrm{~mm}$ ), grade 3 (lesion surrounds the pupil) and grade 4 (lesion crosses the pupil). Results: Pterygium prevalence was $21.2 \%$ for the overall population and $41.1 \%$ in those over 18 years old. Patients between $40-50$ years old were most affected by pterygium. Pterygium data distribution by gender showed that $57.8 \%$ were men. The majority of the patients diagnosed with pterygium was active outdoors $(89.5 \%)$. Subjects affected in both eyes were $75.6 \%$. Of the total population positive to pterygium the majority was grade $1(44 \%)$ and $2(48.7 \%)$. Most of the patients $(85 \%)$ developed nasal pterygium. Conclusion: This study shows one of the highest prevalences of pterygium in the world, covering a Brazilian region never studied before.
\end{abstract}

Keywords: Pterygium/epidemiology; Prevalence; Brazil; Amazon

${ }^{1} \mathrm{MD}$, Resident, Instituto Benjamin Constant - Rio de Janeiro (RJ), Brasil;

${ }^{2} \mathrm{MD}$, Hospital Adventista de Manaus - Manaus (AM), Brasil;

${ }^{3} \mathrm{PhD}$, Universidade Federal do Rio de Janeiro (UFRJ) - Rio de Janeiro (RJ), Brasil;

${ }^{4} \mathrm{MD}$, Fellow, Hospital do Olho - Rio de Janeiro (RJ), Brasil.

${ }^{5} \mathrm{MD}, \mathrm{ONG}$ Enxerga Brasil - Brasil;

${ }^{6} \mathrm{PhD}$, Universidade Estácio de Sá (UNESA) - Rio de Janeiro (RJ), Brasil;

${ }^{7} \mathrm{PhD}$, Instituto Benjamin Constant - Rio de Janeiro (RJ), Brasil and Faculdade de Medicina de Valença - Valença (RJ), Brasil.

From the Instituto Benjamin Constant - Rio de Janeiro (RJ), Brasil

Interest conflitct - None

Recebido para publicação em 9/5/2011 - Aceito para publicação em 26/9/2011

Rev Bras Oftalmol. 2011; 70 (6): 358-62 


\section{RESUMO}

Objetivo: Avaliar a prevalência e as características do pterígio em comunidades ribeirinhas dos rios Solimões e Japurá, estado do Amazonas, Brasil. Métodos: Foi realizado um estudo observacional, em comunidades ribeirinhas dos rios Solimões e Japurá. Os dados foram coletados por dois avaliadores em três expedições médico oftalmológicas, num período de 9 meses, que abrangeram 55 comunidades ribeirinhas, totalizando 1295 pacientes examinados, sendo 659 maiores de 18 anos. Os portadores de pterígio foram analisados através de um questionário abrangendo sexo, idade e atividade laborativa ao sol ou não. O tamanho da lesão foi quantificado em graus. Resultados: A prevalência do pterígio na população geral foi de $21.2 \%$. A prevalência entre os maiores de 18 anos foi de $41.1 \%$. A faixa etária mais acometida foi a de 41 a 50 anos. Dos portadores, $42.2 \%$ eram do sexo feminino e $57.8 \%$ do sexo masculino. $89.5 \%$ dos pacientes acometidos pela lesão trabalhavam ao ar livre. Dos portadores, $75.6 \%$ apresentavam acometimento de ambos os olhos. Dos pacientes acometidos, $48.7 \%$ possuíam pterígio grau $2,44.0 \%$ apresentavam a lesão de grau $1,5.4 \%$ de grau 3 e $1.8 \%$ de grau 4 . Dos olhos acometidos, $85.0 \%$ apresentavam somente pterígio nasal, $2.9 \%$ apresentavam somente pterígio temporal e $14.5 \%$ apresentavam pterígio temporal e nasal. Conclusão: Nosso estudo, nos rios Solimões e Japurá, revelou a existência de uma das maiores taxas de pterígio do mundo, em uma região que nunca havia sido avaliada.

Descritores: Pterígio/epidemiologia; Prevalência; Brasil; Amazônia

\section{INTRODUCTION}

$\mathbf{P}$ terygium is defined as a growth onto the cornea, usually nasally, of a fibrovascular tissue, often triangular in shape, that is continuous with the conjunctiva. This lesion may be clinically aggressive and occasionally threaten vision ${ }^{(1,2)}$. Recent studies suggest that pterygium is a proliferative condition instead of degenerative, highly associated with UV exposure ${ }^{(3-5)}$. The condition is common in the so-called 'pterygium zone', which is defined by a geographical latitude of $40^{\circ}$ north and south of the equator ${ }^{(6)}$. In countries within this area prevalence of up to $22 \%$ in the general population has been reported ${ }^{(7)}$.

The pathogenesis of pterygium is very complex and the subject's genetic background is reported to be relevant in creating and developing pterygium lesions (8).

The communities evaluated in this study are located in the Amazon rain forest, in an isolated region of difficult access, near the equator. The population found in these communities is composed of Indian and whiteindians descent. Their activities are fishing, hunting and agriculture. Almost all the subjects examined have never had contact with an ophthalmologist before. To the present day, there has been no data about prevalence of pterygium in these communities.

In Brazil, there is no data about prevalence of pterygium in the whole country and even for specific regions there are few studies that cover this subject. A previous study of pterygium in Hospitals of Salvador and Manaus showed a similar frequency of the lesion in both genders ${ }^{(9)}$. Another study reported a high incidence of

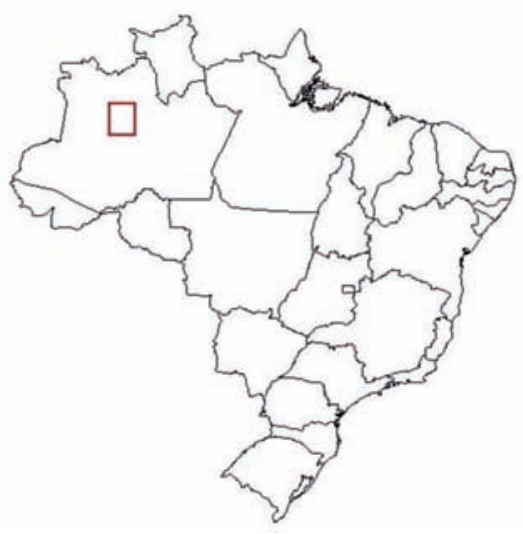

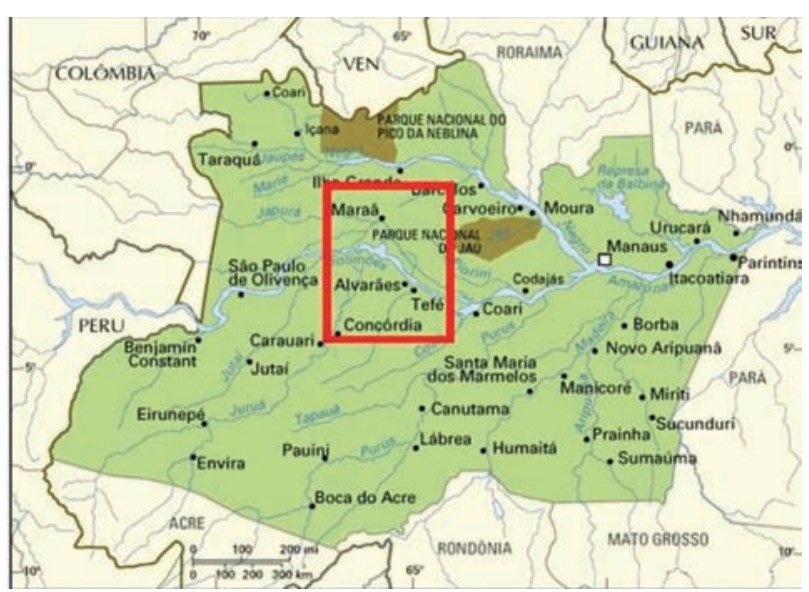

Figure 1: Location of the studied region, Solimões and Japurá rivers, state of Amazonas, Brazil 


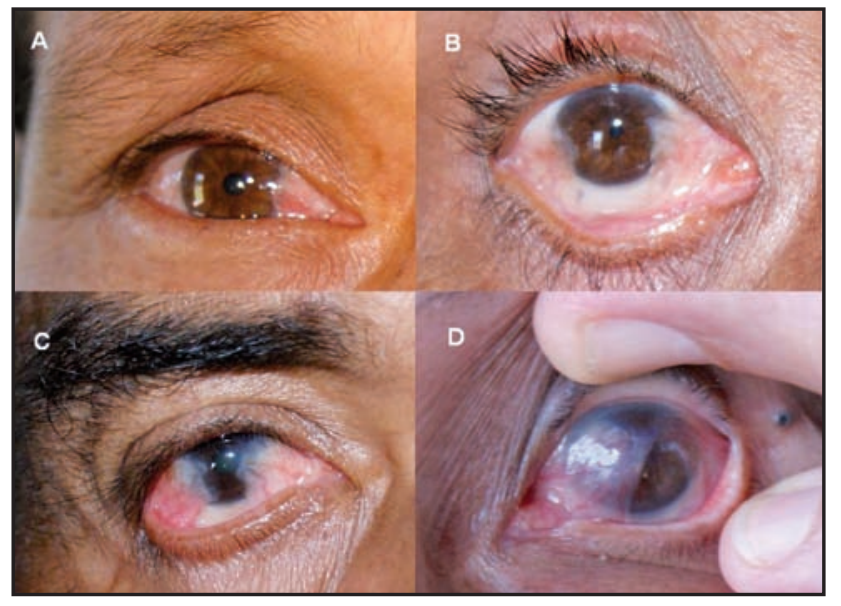

Figure 2: A - Nasal lesion grade 1; B- Temporal and nasal lesion grade 2; C - Temporal and nasal lesion grade 3; D- Temporal and nasal lesion grade 4

pterygium in an institute of ophthalmology in Manaus ${ }^{(10)}$.

Recently pterygium prevalence has been reported among indians at the Negro river region, Amazonas state. According to the reports, a pterygium prevalence of $12.8 \%$ from total Indian population ${ }^{(11)}$ and $18.4 \%$ among elderly and adults was described. Furthermore, pterygium lesions were found mainly in Indian groups with higher UV exposure ${ }^{(12)}$.

The objective of this study is to evaluate pterygium prevalence and characteristcs in small communities of the Amazon rainforest located along the Solimões and Japurá rivers, state of Amazonas, Brazil (Figure 1).

\section{Methods}

A cross-sectional study was developed in small communities along the Solimões and Japurá rivers, located in the countries of Tefé, Alvarães, Maraã and Fonte Boa, state of Amazonas, Brazil. Data were collected by two different evaluators in three medical expeditions. The study covered 55 local communities and 1295 patients. A total of 659 patients were above 18 years old and 636 were under 18 years old. These communities were selected because none of them had never been evaluated by an ophthalomologist before. During each visit, the examiners tried to assess the entire community.

Eyeglasses were donated to patients who needed them. Patients having pterygium lesion answered a questionnaire covering gender, age, and outdoor activity, such as fishing, hunting and agriculture.

The pterygium lesions sizes were graded clinically by slit-lamp biomicroscopy as grade 1 (lesion cover until limbus), grade 2 (lesion covers cornea by $2 \mathrm{~mm}$ ), grade 3 (lesion surrounds the pupil) and grade 4 (lesion crosses the pupil). This graduation was used in the study of pterygium in the the Botucatu region ${ }^{(13)}$. When a individual had more than one lesion, the most severe one was analyzed, as shown in Figure 2. The type of presentation of the lesion was classified as nasal, temporal or both nasal and temporal lesion. This study was approved by the Ethics Committee of the Medical School of Valença. (protocol number 005.0.334.000-10)

\section{Results}

Pterygium was found in $21.2 \%(275 / 1295)$ of all subjects examined. Pterygium prevalence rate between subjects that were above 18 years old was $41.1 \%$ (271/ $659)$. Four patients under 18 years old (15-17 years old) were found with pterygium lesion.

About $26.9 \%$ of the patients that had pterygium were between $41-50$ years old. From total subjects diagnosed with pterygium, $57.8 \%$ (159/275) were male and $42.2 \%(116 / 275)$ were female.

Outdoor activity was referred by $89.4 \%$ (246/275) of the patients with the lesion.

Of total subjects diagnosed with pterygium, $75.6 \%$ (208/275) had it in both eyes.

Out of 483 affected eyes evaluated, $85.1 \%$ (411/ $483)$ showed only nasal lesion, $2.5 \%$ (12/483) only temporal lesion, and $12.4 \%$ (60/483) both temporal and nasal pterygium. Severity assessment in 275 patients demonstrated $44 \%, 48.7 \%, 5.4 \%$ and $1.8 \%$ classified as grade 1 , grade 2 , grade 3 , and grade 4 , respectively (Tables 1 and 2).

\section{Discussion}

The pterygium prevalence along the Solimões and Japurá rivers, of $41.1 \%$ in individuals over 18 years old reported here, is higher than others regions previously reported, such as India, where the prevalence of pterygium in individuals above 50 years of age was $5.2 \%$ (14). In Singapore a prevalence of $9.7 \%$ in those who were over 40 years old has been recorded ${ }^{(15)}$ and in Indonesia a prevalence of $10.0 \%$ in adults over 21 years old ${ }^{(16)}$. In Nigeria there is a prevalence of $8.2 \%$ in individuals from 18 to 49 years old ${ }^{(17)}$.

In this study we showed a higher rate of pterygium than the ones previously described by others in the Amazon rainforest like in the Negro river region where a prevalence of $12.8 \%$ in the population in general ${ }^{(11)}$ and of $18.4 \%$ in adults and elderly had been described ${ }^{(12)}$. 
Table 1

Distribution of commited subjects according age and lesion grade

\begin{tabular}{cccccc}
\hline Age & & \multicolumn{2}{c}{ Grade } & & Total (\%) \\
& G1 & G2 & G3 & G4 & \\
\hline $11-20$ & 5 & 3 & 0 & 0 & $8(2.9)$ \\
$21-30$ & 27 & 18 & 1 & 0 & $46(16.7)$ \\
$31-40$ & 26 & 27 & 2 & 0 & $55(20.0)$ \\
$41-50$ & 29 & 38 & 5 & 2 & $74(26.9)$ \\
$51-60$ & 12 & 26 & 3 & 1 & $42(15.2)$ \\
$>61$ & 22 & 22 & 4 & 2 & $50(18.1)$ \\
$11-20$ & 5 & 3 & 0 & 0 & $8(2.9)$ \\
Total (\%) & $121(44.0)$ & $134(48.7)$ & $15(5.4)$ & $5(1.8)$ & $275(100)$ \\
\hline
\end{tabular}

Table 2

Distribution of commited subjects with pterygium according to gender and lesion grade. $\mathrm{F}$ - female; $\mathrm{M}$ - male

\begin{tabular}{cccc}
\hline Grade & F & M & Total (\%) \\
\hline G1 & 55 & 66 & $121(44.0)$ \\
G2 & 54 & 80 & $134(48.7)$ \\
G3 & 6 & 9 & $15(5.4)$ \\
G4 & 1 & 4 & $5(1.8)$ \\
Total & $116(42.2)$ & $159(57.8)$ & $275(100)$ \\
\hline
\end{tabular}

The severity of the lesion is important in this study. The pterygium observed was classified mainly as grade 2 and grade 1 , but lesions in grade 4 , that causes a severe visual acuity disability, were found in 5 subjects, suggesting that it may still exist blindness caused by pterygium in that region. Furthermore, we showed that four patients under 18 years old and 48 patients with ages between 19 e 30 years old developed pterygium. From total subjects diagnosed with pterygium, 39.6\% were under 40 years old. This data suggests that pterygium develops early in the population studied.

The outdoor activities such as fishing, hunting and agriculture were the occupation of most of the patients. This suggests the relationship between exposure to UV and the development of pterygium, already demonstrated in other $\operatorname{articles}^{(3,18)}$.

\section{Conclusion}

Considering the difficulty of access to the communities evaluated, this study had a large area of coverage and a larger number of inhabitants were included than in other studies in the Amazon region. In conclusion, this work described one of the highest pterygium rates in the world, in an Amazon region that had never had been studied before, showing the importance of further studies of the riverside population in the Amazon rainforest.

\section{Acknowledgments}

NGO Enxerga Brasil, Brazilian Army, Mamirauá Institute

\section{REFERENCES}

1. Duke-Elder S, Leigh AG. Diseases of the outer eye. In: DukeElder S, editor. System of ophthalmology. St. Louis: Mosby; 1965. vol. 8. p. 573-4

2. Yanoff M, Duker JS, editors. Ophthalmology. 3rd ed. St. Louis: Mosby; 2009. p. 248-9.

3. Detorakis ET, Spandidos DA. Pathogenetic mechanisms and treatment options for ophthalmic pterygium: trends and perspectives (Review). Int J Mol Med. 2009;23(4):439-47.

4. Threlfall TJ, English DR. Sun exposure and pterygium of the eye: a dose-response curve. Am J Ohthalmol. 1999;128(3):280-7.

5. Portes AJF, Elias CA, Laje C, Jordão LF, Lyrio NM. Efeito do filtro de ultravioleta em lentes de contato hidrofílicas de alta hidratação. Rev Bras Oftalmol. 2008;67(3):114-8. 
6. Coroneo MT. Pterygium as an early indicator of ultraviolet insolation: a hypothesis. Br J Ophthalmol. 1993;77(11):734-9.

7. Hilgers JH. Pterygium: its incidence, heredity and etiology. Am J Ophthalmol. 1960;50:635-44.

8. Di Girolamo N, Chui J, Coroneo MT, Wakefield D. Pathogenesis of pterygia: role of cytokines, growth factors, and matrix metalloproteinases. Prog Retin Eye Res. 2004;23(2):195-228.

9. Garrido Neto T, Garrido C, Carvalho RC, Lima HC. Estudo da frequência de pterígio em Hospitais de Salvador e Manaus. Rev Bras Oftalmol. 1996;55(9):683-6.

10. Chaves C, Cohen JM. Pterígio. Rev Bras Oftalmol. 1985;44(5):196.

11. Reis ACPP, Chaves C, Cohen JM, Belfort F, Oliveira NP, Belfort Júnior R. Detecção de tracoma e doenças corneanas em índios da região do Alto Rio Negro. Arq Bras Oftalmol. 2002;65(1):79-81.

12. Paula JS, Thorn F, Cruz AA. Prevalence of pterygium and cataract in indigenous populations of the Brazilian Amazon rain forest. Eye (Lond). 2006;20(5):533-6.

13. Schellini SA, Veloso CER, Lopes W, Padovani CR, Padovani CRP. Características de portadores de pterígio na região de Botucatu. Arq Bras Oftalmol. 2005;68(3):291-4.
14. Singh MM, Murthy GV, Venkatraman R, Rao SP, Nayar S. A study of ocular morbidity among elderly population in a rural area of central India. Indian J Ophthalmol. 1997;45(1):61-5.

15. Wong TY, Foster PJ, Johnson GJ, Seah SK, Tan DT. The prevalence and risk factors for pterygium in an adult Chinese population in Singapore: the Tanjong Pagar survey. Am J Ophthalmol. 2001;131(2):176-83.

16. Gazzard G, Saw SM, Farook M, Koh D, Widjaja D, Chia SE, et al. Pterygium in Indonesia: prevalence, severity and risk factors. Br J Ophthalmol. 2002;86(12):1341-6.

17. Nowosu SN. Ocular problems of young adults in rural Nigeria. Int Ophthalmol. 1998;22(5):259-63.

18. Taylor HR. Ultraviolet radiation and the eye: an epidemiologic study. Trans Am Ophthalmol Soc. 1989;87:802-53.

Endereço para correspondência:

Lívia Adnet Ribeiro

Rua Gilberto Cardoso, no 280, apto 504

CEP 22430-070 - Rio de Janeiro (RJ), Brasil

E-mail: liv_adnet@yahoo.com.br 